Review

\title{
Sericin for Tissue Engineering
}

\author{
You-Young Jo ${ }^{1}$, HaeYong Kweon ${ }^{1}$ and Ji-Hyeon $\mathrm{Oh}^{2, *(1)}$ \\ 1 Sericultural and Apicultural Division, National Institute of Agricultural Science, Rural Development \\ Administration, Wanju 55365, Korea; yyjo@korea.kr (Y.-Y.J.); hykweon@korea.kr (H.K.) \\ 2 Department of Oral and Maxillofacial Surgery, College of Dentistry, Gangneung-Wonju National University, \\ Gangneung 25457, Korea \\ * Correspondence: haruna348@naver.com; Tel.: +82-33-640-3072
}

Received: 4 November 2020; Accepted: 25 November 2020; Published: 27 November 2020

\begin{abstract}
Sericin is a 10-to-400 $\mathrm{kDa}$ hydrophilic protein with high serine content and is a silk constituent together with fibroin. It is produced in the middle silk gland of the silkworm and encoded by four sericin genes. The molecular weight of sericin and its biological activity vary depending on the extraction method employed. Its chemical structure, in terms of random coil and $\beta$-sheet conformations, also differs with the extraction method, thereby extending its applications in various fields. Sericin, which was discarded in the textile industry in the past, is being applied and developed in the biomedical field, owing to its biological properties. In particular, many studies are underway in the field of tissue engineering, evaluating its applicability in burn dressing, drug delivery, bone regeneration, cartilage regeneration, and nerve regeneration.
\end{abstract}

Keywords: sericin; Bombyx mori; genes; degumming method; molecular weight; tissue engineering; burns; drug delivery system; bone regeneration; cartilage regeneration; nerve regeneration

\section{Introduction}

Raw silk produced by Bombyx mori is a natural protein fiber comprising hydrophobic fibroin and hydrophilic sericin [1-3]. Fibroin is a core filament that provides stiffness and strength and makes up more than $70 \%$ of the cocoon. Sericin makes up $20-30 \%$ of the cocoon and is a glue-like protein that binds fibroin fibers together [4-6].

For a long time, silk sericin was discarded in the silk industry through a degumming process to improve the value of silk as a textile fiber and simply regarded as waste [1,2]. Fibroin exhibits low inflammatory activity, excellent biocompatibility and mechanical properties, and controllable degradability; hence, many studies have been conducted on its non-textile applications, especially medical applications [7-10], and it has been widely used in membranes for guided bone regeneration [6,11,12], scaffolds for tissue engineering [13-17], wound dressing [18-20], cornea tissue engineering [21], artificial eardrums [22], vascular grafts [23,24], nerve guidance conduits [25], and drug delivery carriers [26].

Only recent reports on new functions of sericin have demonstrated its beneficial properties such as biocompatibility [27], biodegradability, collagen production, and anti-oxidative, anti-tyrosinase, anti-inflammatory, anticoagulatory, antitumor, anti-aging, and anti-wrinkle effects [5,10,28-31]. Therefore, sericin has been applied in wound dressing [32-36], corneal abrasion treatment [37,38], cell culture media [39-43], anticancer drugs [32], and cosmetics for skin, nails and hair [44,45].

The purpose of this paper is to report the recently updated information on sericin genes and their influence on the molecular weight and biological activities of sericin depending on the degumming method, as well as to review the application of sericin in tissue engineering. 


\section{Sericin as a Degumming Product}

\subsection{Sericin Gene}

Sericin proteins are synthesized by alternative splicing of sericin genes, which are regulated as per different phases of larval development [32]. Sericin proteins are synthesized in the middle silk gland (MSG) of the silkworm, B. mori [46]. Until now, four sericin genes have been reported, namely, sericin1, sericin2, sericin3, and sericin4, all of which are located on chromosome 11 [47].

The first discovered gene was that encoding sericin 1, which is approximately $24 \mathrm{~kb}$ long and contains nine axons $[48,49]$. This gene can be alternatively spliced as four mRNAs $(10.5,9.0,4.0$, and $2.8 \mathrm{~kb}$ ) [50-52]. The sericin 2 gene is approximately $16.2 \mathrm{~kb}$ long and comprises 13 exons [50,51]. It can be alternatively spliced as two mRNAs (3.1 and 5.0-6.4 kb) [51]. The organization of sericin 2 is similar to that of sericin 1 in that the first two exons are similar in size and encode the signal peptide [53]. Takasu et al. discovered sericin 3 with a size of $6.6 \mathrm{~kb}$ and a transcript of $4.9 \mathrm{~kb}$ containing 3 exons [54]. The most recently discovered gene, sericin 4 , is approximately $40 \mathrm{~kb}$ in size and contains 34 exons. It was identified to have six alternatively spliced transcripts [47].

Sericin 1 and 4 proteins are synthesized in the middle and posterior part of the MSG; however, sericin 2 and 3 proteins are synthesized in the anterior part of the MSG (Figure 1) [47,54-56]. Sericin 1 is synthesized from the first to the fifth instar, while sericin 2 is synthesized from the first instar to the fifth day of the fifth instar [55,57]. Sericin 3 is synthesized only after the fifth day of the fifth instar, while sericin 4 is synthesized from the first instar to the fourth instar $[47,57]$.

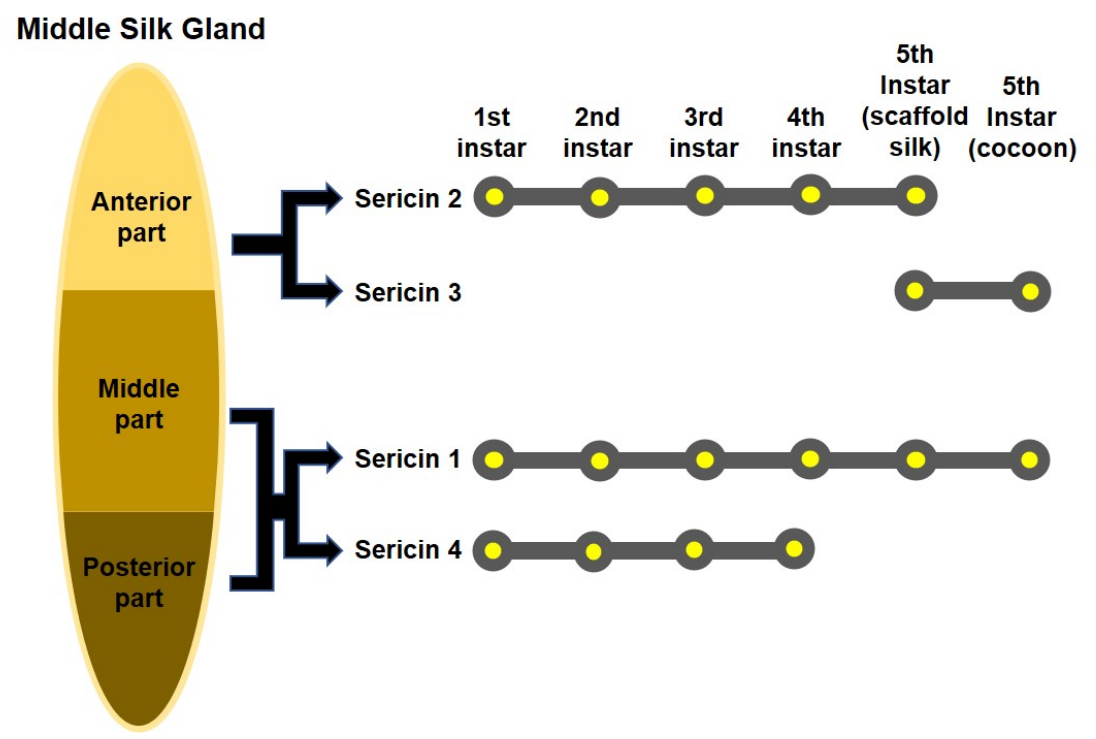

Figure 1. The middle silk gland of the silkworm and sericin gene expression.

Silkworms produce two types of silk: cocoon silk and non-cocoon silk. As the synthesis locations of proteins in the silk gland determine their position in silk, the innermost and outmost sericin layers in cocoon silk comprise of sericin 1 and 3, respectively, whereas the outer and inner sericin layers in non-cocoon silk consist of sericin 2 and 4, respectively [32,47,55]. Non-cocoon silk with sericin 2 and 4 may exhibit better adhesion than cocoon silk with sericin 1 and 3, because sericin 2 and 4 have a higher percentage of charged amino acids than others [47,53]. In addition, sericin 2 and 4 contain fewer serine residues than sericin 1 and 3, suggesting that sericin proteins in non-cocoon silk form fewer $\beta$-sheet structures than those in cocoon silk $[47,52,54,55]$. The structural differences in sericin consistent with the distribution of sericin proteins in these two types of silk are also reflected in functional differences [47]. Sericin 1 and 3, the main components of the cocoon shell, have a rather rigid structure that forms the cocoon. In contrast, sericin 2 and 4 have adhesive properties, necessary 
to anchor the larval body to the surrounding material, such as a tree branch, without the need to form a rigid structure $[47,53,55]$.

\subsection{Sericin Molecular Weight and Degumming Process}

Sericin, composed of 18 amino acids, is a water-soluble globular protein with molecular weights ranging from 10 to $400 \mathrm{kDa}$ [29,30,32,58]. Its molecular weight varies depending on the extraction method employed [58,59]. Several strategies have been used for the extraction of sericin from the cocoon of B. mori, including extraction using high temperature, with or without high pressure, acids, alkalis, urea, and enzymes $[32,58,60]$. Degumming conditions such as temperature, time, chemical additives, and solution concentrations can be modified to achieve better efficacy [32]. The extraction yield and the morphology of cocoon extracts vary depending on the degumming conditions such as solvent and temperature (Figure 2). In addition, protein content and molecular weight vary depending on the degumming conditions (Figure 3). The chemical structure of cocoon extracts changes as per these conditions (Figure 4). The higher the concentration of ethanol (EtOH) and the lower the temperature, the higher is the crystallinity. The random coil and $\beta$-sheet conformations of cocoon extracts also change based on the degumming conditions (Figure 5 and Table 1).

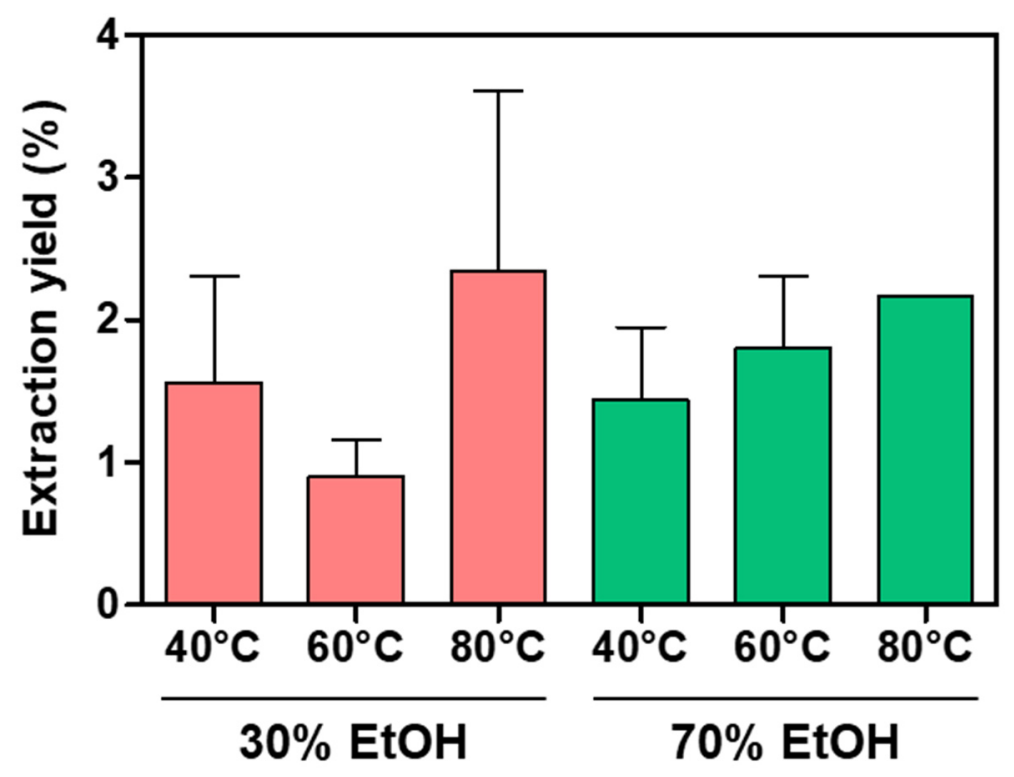

(a)

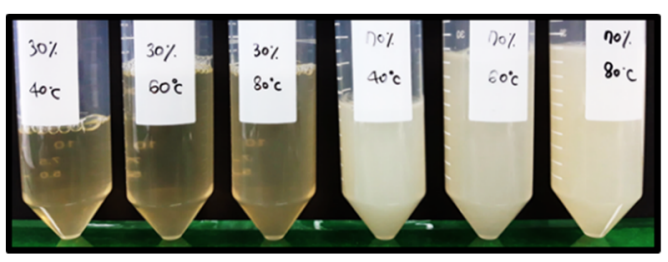

(b)

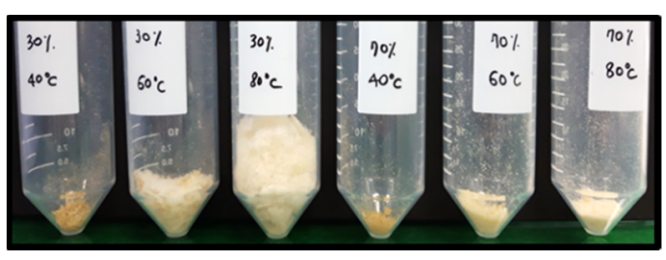

(c)

Figure 2. Effects of extraction conditions on the extraction yields and morphologies of cocoon extracts. (a) Extraction yields (\%) calculated by dividing the solid component in the various extracts by the weight of input cocoons. (b) Cocoon extracts solutions after concentration by an evaporator. (c) Cocoon extract powders obtained by lyophilization. 


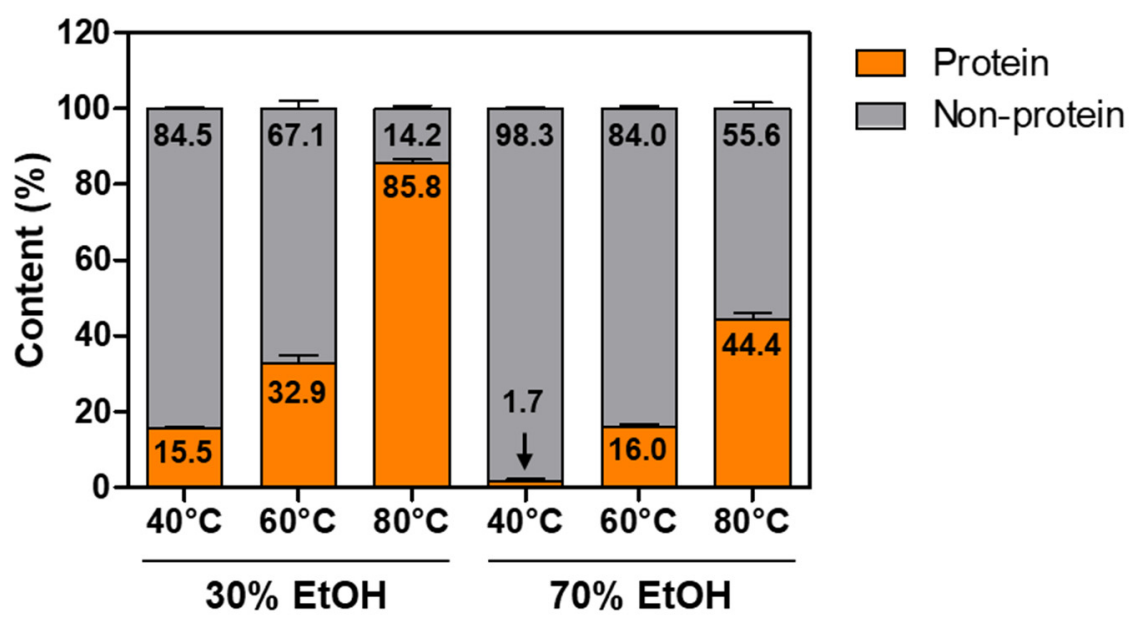

(a)

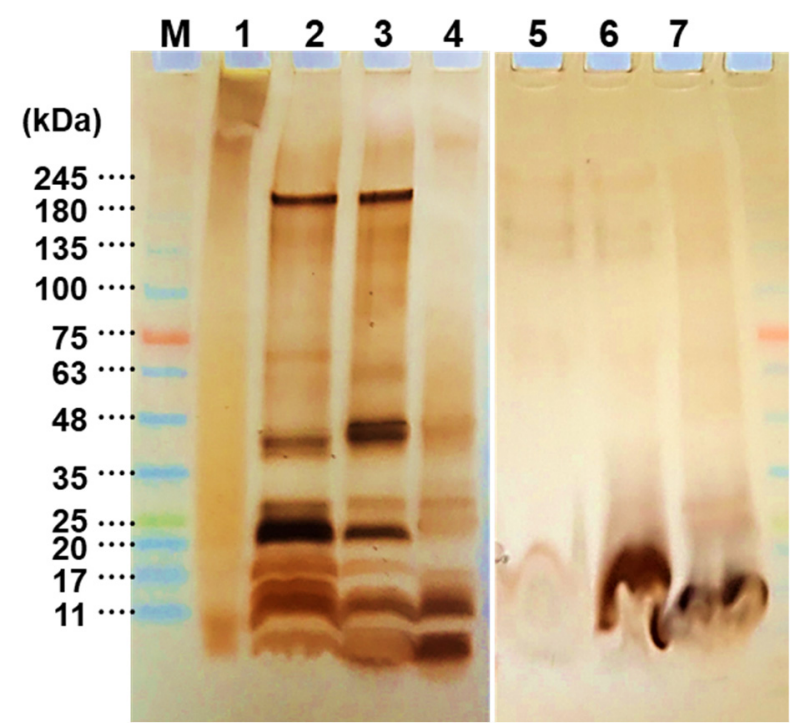

(b)

Figure 3. Effects of extraction conditions on protein content (\%) and molecular weight of proteins. (a) Percentage of protein and non-protein fractions included in the extracts. (b) SDS-PAGE results for various cocoon extracts. Lane " $\mathrm{M}$ " and "1"-" 4 " indicate marker $(\mathrm{M})$, silk sericin extracted by using a hot water system (1), cocoon extracts prepared by $30 \%$ ethanol $(\mathrm{EtOH})$ at $40{ }^{\circ} \mathrm{C}(2), 60^{\circ} \mathrm{C}(3), 80^{\circ} \mathrm{C}$ (4), respectively. Lanes " $5 "-" 7$ " indicate cocoon extracts prepared by $70 \% \mathrm{EtOH}$ at $40^{\circ} \mathrm{C}(5), 60^{\circ} \mathrm{C}(6)$, $80{ }^{\circ} \mathrm{C}(7)$, respectively. 


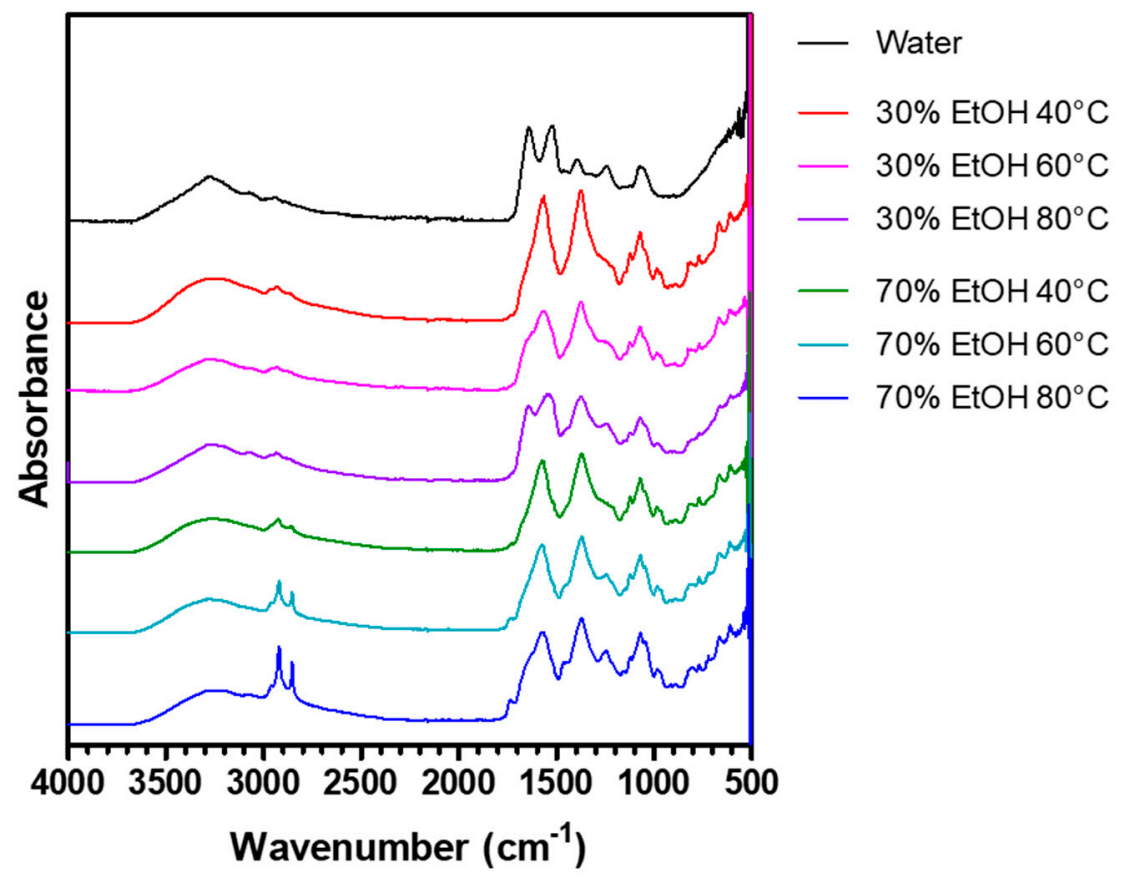

(a)
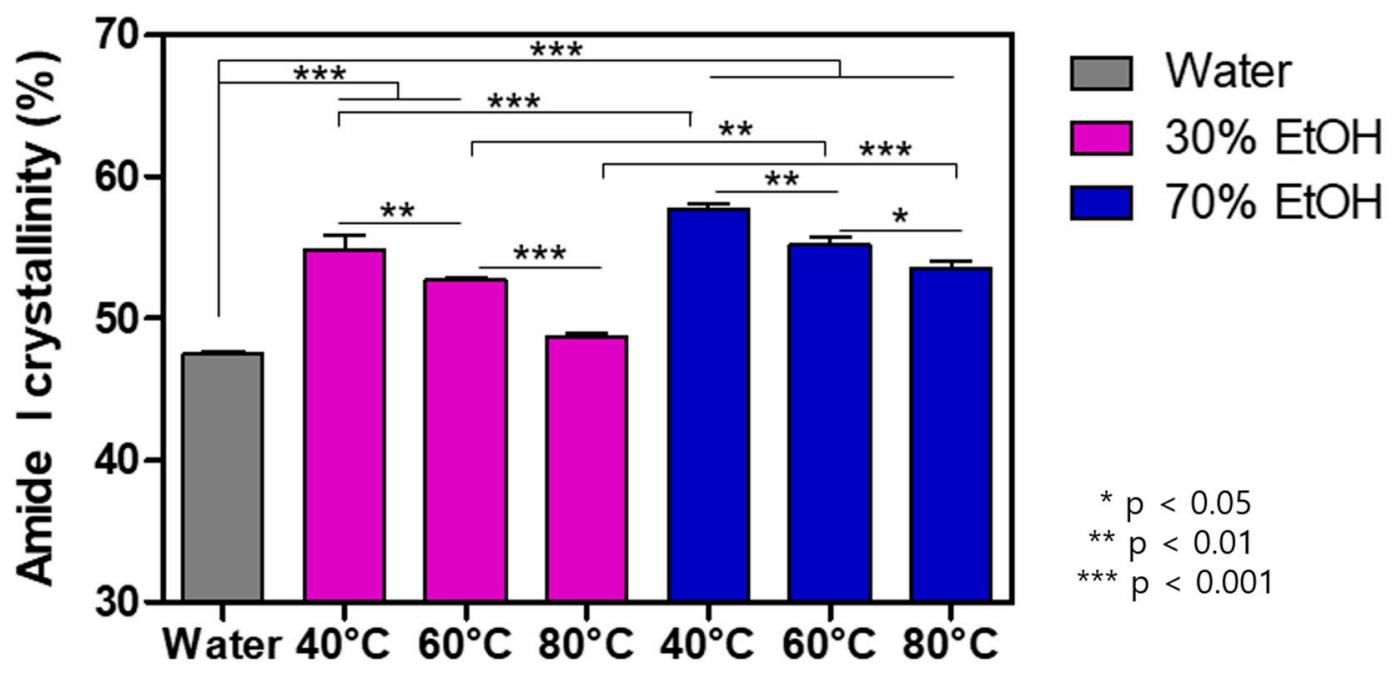

(b)

Figure 4. Effects of extraction conditions on the chemical structure of cocoon extracts. (a) FTIR spectra and (b) amide I crystallinity index of various cocoon extracts. A cocoon extract prepared using the hot water extraction system was considered as a control. ${ }^{*} p<0.05,{ }^{* *} p<0.01,{ }^{* * *} p<0.001$. 


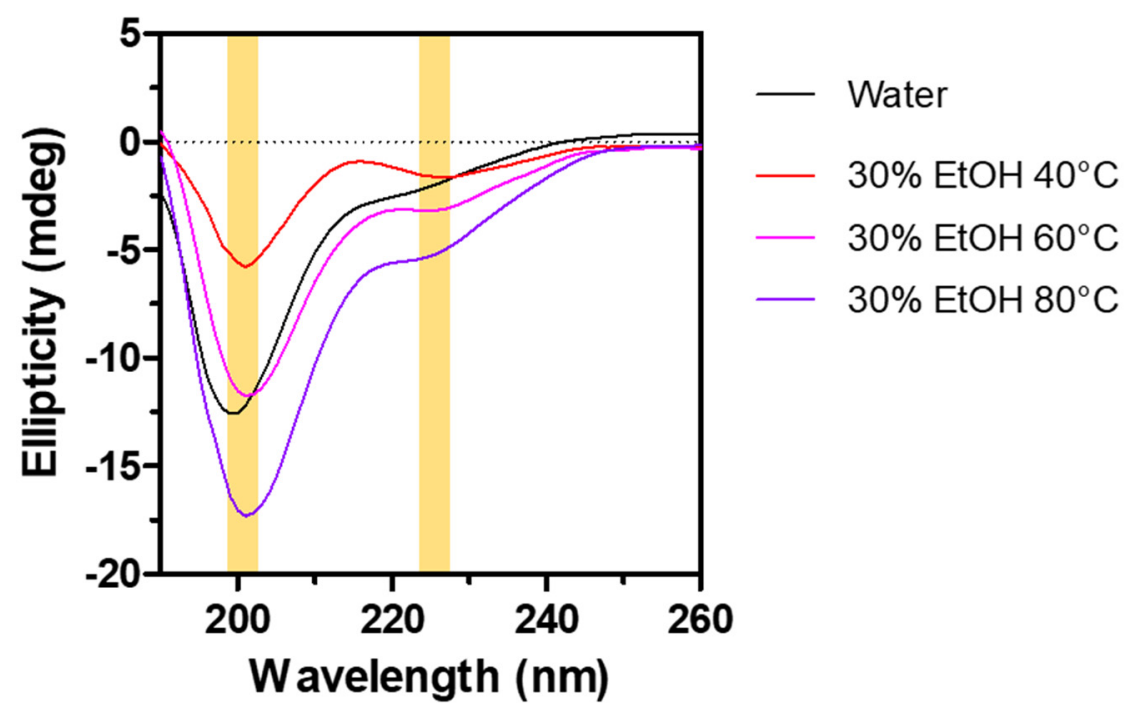

(a)

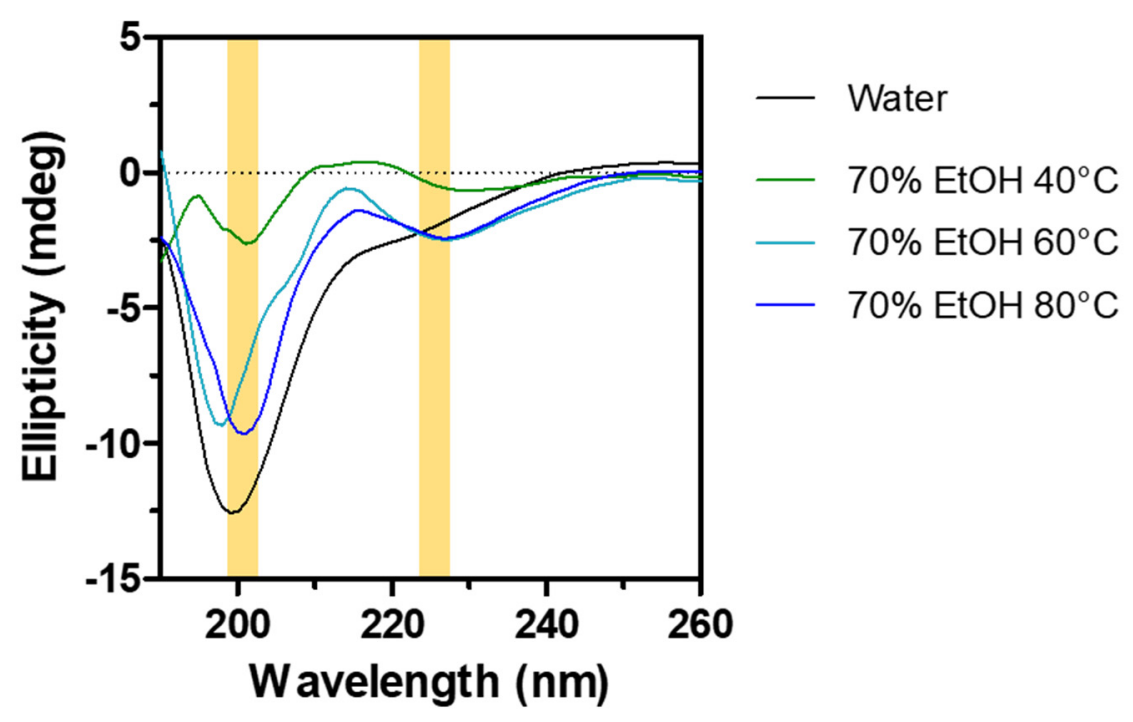

(b)

Figure 5. Effects of extraction conditions on the conformations of cocoon extracts in aqueous solution. $\mathrm{CD}$ spectra of various cocoon extracts prepared in $30 \%$ ethanol (a) and $70 \%$ ethanol (b) at $40{ }^{\circ} \mathrm{C}$, $60{ }^{\circ} \mathrm{C}$, and $80{ }^{\circ} \mathrm{C}$. A cocoon extract prepared by the hot water extraction system was considered as a control. Yellow marks indicate the wavelengths corresponding to random coil and $\beta$-sheet conformations, respectively. 
Table 1. Calculated conformations of various cocoon extracts prepared by using different solvents at different temperatures.

\begin{tabular}{cccccc}
\hline Sample & & Helix & Sheet & Turn & Others \\
\hline Hot water extracts & $3.40 \%$ & $34.40 \%$ & $14.20 \%$ & $48.00 \%$ \\
\hline \multirow{2}{*}{$30 \%$ EtOH extracts } & $40{ }^{\circ} \mathrm{C}$ & $2.30 \%$ & $39.50 \%$ & $13.90 \%$ & $44.30 \%$ \\
\cline { 2 - 5 } & $60{ }^{\circ} \mathrm{C}$ & $4.30 \%$ & $37.10 \%$ & $14.10 \%$ & $44.50 \%$ \\
\cline { 2 - 5 } & $80{ }^{\circ} \mathrm{C}$ & $6.90 \%$ & $33.90 \%$ & $14.90 \%$ & $44.30 \%$ \\
\hline \multirow{3}{*}{$70 \%$ EtOH extracts } & $40{ }^{\circ} \mathrm{C}$ & $0.60 \%$ & $41.90 \%$ & $13.40 \%$ & $44.10 \%$ \\
\cline { 2 - 5 } & $60{ }^{\circ} \mathrm{C}$ & $0.60 \%$ & $41.40 \%$ & $13.60 \%$ & $44.40 \%$ \\
\cline { 2 - 6 } & $80{ }^{\circ} \mathrm{C}$ & $1.70 \%$ & $40.10 \%$ & $13.80 \%$ & $44.40 \%$ \\
\hline
\end{tabular}

Sericin extracted by the conventional method of boiling have a molecular weight of 10 to $220 \mathrm{kDa}$ [61], while those extracted by the high-temperature and high-pressure degumming technique (autoclaving) have molecular weights ranging from 20 to $400 \mathrm{kDa}$ [62]. Sericin extracted by the acid-degradation method has a molecular weight in the range of $35-150 \mathrm{kDa}$, while that extracted by the alkali-degradation method has a molecular weight in the range of 15-75 kDa [63]. Sericin extracted with a urea solution was found to have a molecular weight in the range of 10 to $>225 \mathrm{kDa}$ [64].

\subsection{Cellular Response to Sericin and Influence of the Degumming Method on Sericin Biological Activity}

Sericin is a fundamental insect protein produced by the silkworm. There is no doubt that it is a foreign protein and hence immunogenic to humans. While some studies stated sericin to be a biocompatible and non-immunogenic protein, this should be accepted as a relative statement in comparison with highly immunogenic foreign proteins. Even human proteins may be immunogenic upon denaturation. As mentioned, different degumming processes produce different yield ratios and protein structures. Considering that protein structure is the main determinant of its biological response, the degumming process may influence sericin activity. The effects of the degumming process on the macrophage response and $\beta$-sheet content of silk fibroin have been documented [65]. As the silkworm cocoon protects the larva from the outer environment, sericin is assumed to have antibacterial properties. However, a recent paper proved that sericin lacks antibacterial properties [66].

Sericin may be an allergen for some people [67]. Immunogenic responses to sericin have been studied in RAW264.7 cells. Insoluble fibroin particles, but not soluble sericin, significantly increased tumor necrosis factor- $\alpha$ (TNF $\alpha$ ) levels [27]. When sericin was administered to mouse monocytes and alveolar macrophages, the levels of TNF $\alpha$ and interleukin-1 $\beta$ (IL1 $\beta$ ) increased in a dose-dependent manner [68]. Interestingly, these elevated levels of TNF $\alpha$ and IL1 $\beta$, following sericin administration, did not result in delayed wound healing in animal models [68]. Similarly, sericin increased the TNF $\alpha$ level in RAW264.7 cells, but a silk mat with sericin enhanced new bone formation in the rat calvarial defect model [69]. Sericin also activated the nuclear factor kappa B (NF- $\kappa B$ ) pathway, which is implicated in the inflammation of retinal pigment epithelial cells [70]. Sericin increased vascular endothelial growth factor (VEGF) in RAW264.7 cells through elevation of hypoxia inducible factor (HIF) expression [71]. The administration of sericin increased VEGF expression in human umbilical vein cells [72]. A silk mat produced by cutting and peeling off $B$. mori cocoons was tested for bone regeneration in the extraction socket of humans [73]. The soluble proteins (mainly sericin) released from these silk mats increased the expression of the genes associated with angiogenesis such as VEGF and inflammation (IL1 $\beta$ and TNF $\alpha$ ) (Figure 6) [74]. Sericin was shown to elevate the expression levels of IL1 $\beta$, TNF $\alpha$, and VEGF $[68,69,71]$. When sericin was fractioned according to its molecular weight, the fraction with higher molecular weight increased TNF $\alpha$ expression in RAW264.7 cells more than that with lower molecular weight [75]. 


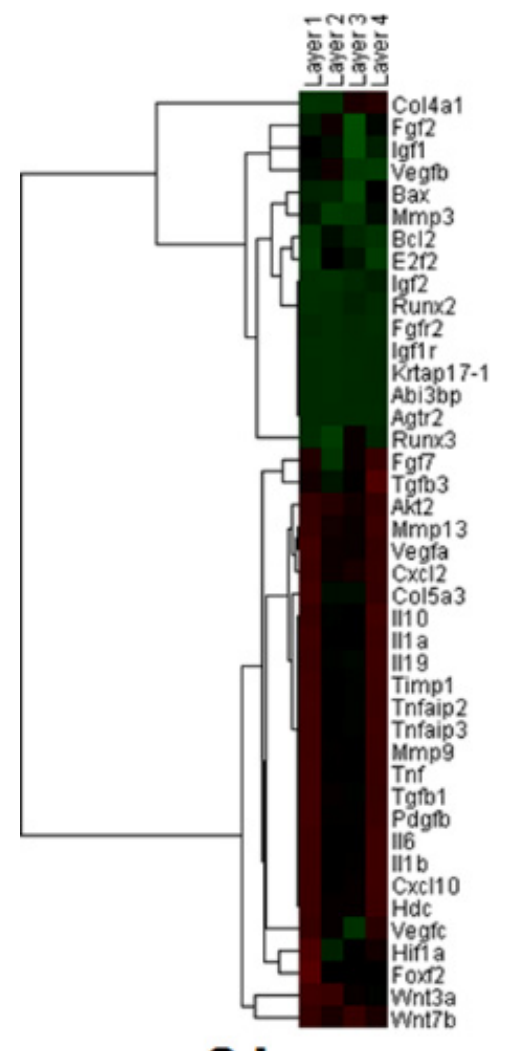

2 hr

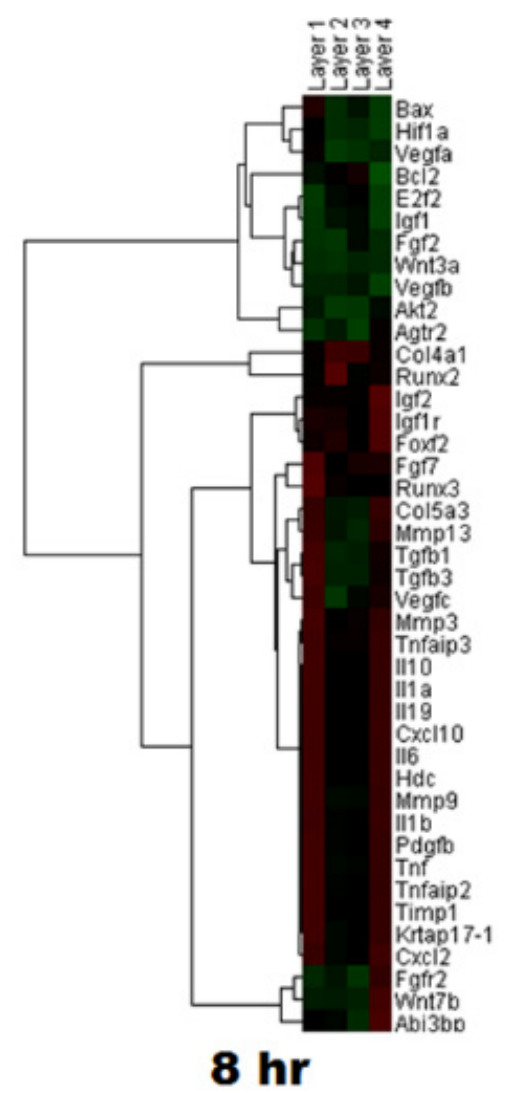

Figure 6. cDNA microarray analysis. The application of soluble proteins from a silk mat changed the expression levels of genes after $2 \mathrm{~h}$ and $8 \mathrm{~h}$. Layer 1 was obtained from the innermost layer of silkworm cocoon, and Layer 4 from the outermost layer (Reproduced from a published article [74] with permission).

Unlike most publications, some studies have reported the anti-inflammatory potential of sericin. Topical application of sericin $(80 \mu \mathrm{g} / \mathrm{mL})$ could significantly lower cyclooxygenase (COX)-2 levels as compared to water application in a carrageenan-induced inflammation model [76]. While sericin alone could not reduce lipopolysaccharide-induced serum TNF $\alpha$ expression, naringenin-loaded sericin reduced this effect [77]. The amelioration of TNF $\alpha$ levels in the naringenin-loaded sericin group was stronger than that observed in the naringenin group [77]. Sericin exhibited a protective effect similar to that of metformin in the kidneys of rats with diabetic nephropathy through the suppression of the transforming growth factor (TGF)- $\beta 1 / \mathrm{Smad} 3$ pathway [78]. Sericin may also exert antioxidant activities, which highly vary depending on the species that produced it [31]. Sericin extracted from Antheraea mylitta cocoon was applied to AH927 cells and was found to reduce the oxidative stress induced by hydrogen peroxide [79]. Sericin inhibited lipid peroxidation and tyrosinase activity [44] and accelerated the attachment of human dermal fibroblasts in culture [80]. Sericin from B. mori stimulated cellular migration via the c-Jun mediated pathway [81] and increased the expression of osteocalcin and alkaline phosphatase in osteoblasts cultured on sericin-coated titanium surface [82].

The thermal stability of sericin varies depending on the chemicals used for its extraction [63]. Further, the biological activity of sericin also varies owing to differences in its molecular weight and amino acid composition, depending on the extraction method [29,32]. The biological response to sericin is highly dependent on the extraction method used. Sericin extracted by urea is highly toxic to cells, but heat-degraded sericin is relatively non-toxic [64]. In terms of anti-tyrosinase activity, sericin extracted using urea exhibits higher activity than alkali-degraded sericin [63]. Tyrosinases are copper-containing enzymes that catalyze the conversion of monophenol to ortho-quinone [83]. Sericin 
plays the role of an antioxidant and inhibits tyrosinase activity [84]. It may be useful for the treatment and prevention of reactive oxygen species (ROS)-related diseases, including cancer, neurodegenerative diseases, diabetes, and cardiovascular dysfunction $[85,86]$. The comparison of the antioxidant activities of sericin proteins extracted by different methods showed that sericin extracted by the alkali method had the best activity, followed by that prepared by autoclaving and the conventional method [29]. During degumming, sericin undergoes fragmentation, and hence, has different molecular weights. The molecular weight of sericin has a marginal effect on cellular toxicity [1]. However, the crystallization and mechanical properties of sericin improve with an increase in its molecular weight [1]. Therefore, the in vivo response to sericin may also differ based on its molecular weight. The various biological activities associated with each degumming method are summarized in Table 2.

Table 2. Molecular weight and biological activity of sericin according to the degumming method used.

\begin{tabular}{|c|c|c|c|}
\hline Extraction Technique & Molecular Weight & Biological Activity & Reference \\
\hline $\begin{array}{l}1.25 \% \text { citric acid solution heated for } 30 \mathrm{~min} \\
0.5 \% \mathrm{Na}_{2} \mathrm{CO}_{3} \text { solution heated for } 30 \mathrm{~min} \\
8 \mathrm{M} \text { urea for } 30 \mathrm{~min} \text { followed by heating at } \\
85^{\circ} \mathrm{C} \text { for } 30 \mathrm{~min}\end{array}$ & from 10 to $>225 \mathrm{kDa}$ & $\begin{array}{l}\text { Sericin extracted using urea exhibited } \\
\text { the highest cell toxicity and the lowest } \\
\text { induction of collagen production, while } \\
\text { sericin extracted by the autoclaving } \\
\text { method showed the lowest cell toxicity } \\
\text { and the highest induction of } \\
\text { collagen production. }\end{array}$ & [64] \\
\hline $\begin{array}{c}\text { Autoclaving at } 120^{\circ} \mathrm{C} \text { for } 60 \mathrm{~min} \\
1.25 \% \text { citric acid solution heated for } 30 \mathrm{~min} \\
0.5 \% \mathrm{Na}_{2} \mathrm{CO}_{3} \text { solution heated for } 30 \mathrm{~min} \\
8 \mathrm{M} \text { urea for } 30 \mathrm{~min} \text { followed by heating at } \\
85^{\circ} \mathrm{C} \text { for } 30 \mathrm{~min}\end{array}$ & $\begin{array}{c}\text { 35-150 kDa } \\
35-150 \mathrm{kDa} \\
15-75 \mathrm{kDa} \\
\text { from } 10 \text { to }>225 \mathrm{kDa}\end{array}$ & $\begin{array}{l}\text { Compared to other extraction methods, } \\
\text { sericin extracted using urea exhibited } \\
\text { the highest antityrosinase activity. }\end{array}$ & [63] \\
\hline $\begin{array}{l}\text { Autoclaving at } 120{ }^{\circ} \mathrm{C} \text { for } 20 \mathrm{~min} \\
1.25 \% \text { citric acid solution heated for } 30 \mathrm{~min} \\
0.5 \% \mathrm{Na}_{2} \mathrm{CO}_{3} \text { solution heated for } 30 \mathrm{~min} \\
8 \mathrm{M} \text { urea for } 30 \mathrm{~min} \text { followed by heating at } \\
85^{\circ} \mathrm{C} \text { for } 30 \text { min } \\
0.02 \mathrm{M} \mathrm{Na}_{2} \mathrm{CO}_{3} \text { solution heated for } 30 \mathrm{~min}\end{array}$ & $\begin{array}{c}\text { smear } \\
\text { smear } \\
\text { smear with a clear band } \\
\text { at } 75 \mathrm{kDa} \\
10-120 \mathrm{kDa} \\
\text { smear }\end{array}$ & $\begin{array}{l}\text { Sericin extracted by the } \\
\text { alkali-degradation method showed } \\
\text { higher efficacy in antioxidant potential } \\
\text { than conventional or } \\
\text { autoclaving methods. }\end{array}$ & [29] \\
\hline
\end{tabular}

Conflicting results from cellular experiments using sericin may be attributed to the following reasons. First, many papers did not describe sufficiently the extraction method of sericin that was employed. Considering the biological effect of the extraction method, the discrepancy in the biological response to sericin may be attributed to the differences in the extraction methods. Second, the biological response to sericin may be different depending on the species it was obtained from. Most studies tested sericin proteins from B. mori or A. mylitta; their species-dependent activities have already been well demonstrated [31]. Third, the biological response to sericin may be also different depending on sericin molecular weight; however, there have been few papers about this. If high-molecular-weight sericin is more effective than low-molecular-weight sericin, sericin fragments can be separated as fractions based on their molecular weights, after extraction from cocoons. Considering that sericin is a protein, most cellular responses may be mediated via cell surface receptors. As human cell receptors corresponding to sericin have rarely been studied, cellular responses specific to sericin have not been elucidated in detail.

\section{Sericin and Tissue Engineering}

\subsection{Sericin for Burn Dressing}

Wound healing is a dynamic and complex process involving a highly organized and coordinated series of events $[30,87]$. Theses complex events occur in four overlapping phases: hemostasis, inflammation, proliferation, and remodeling [30,87-89]. Chronic wounds such as burns, diabetic wounds, and ulcers result in tissue injury, which becomes irreparable within a typical time period due to disturbance by various factors that prolong one or more of the four normal healing phases $[87,90]$. 
A burn is a tissue lesion characterized by changes varying from local erythema to complete destruction of the affected structure [91]. Burns are associated with significant mortality and disability, multiple surgeries, longer period of hospitalization and rehabilitation, and high medical costs [92]. The purpose of managing and treating burns is to induce epithelialization as quickly as possible for prevention of infection and reduction of functional and aesthetic sequelae [91]. Burns often lead to sepsis; hence, topical antimicrobial agents are always prophylactically administered to prevent the complications of infections [92].

Silk sericin has been directly used in regenerative medicine to maintain the proliferation of keratinocytes and fibroblasts during the wound healing process [93]. It can induce fibroblast proliferation and collagen production without the activation of pro-inflammatory cytokines [64,68,94,95]. Further, it can be formulated and used as a wound dressing or cream to control wound infection [30] and employed to treat burns, reduce scarring, and prevent infection [91]. The antioxidant activity of silk sericin may help in the scavenging of ROS generated in chronic wounds. Therefore, sericin-containing substances may prevent the prolonged inflammation of chronic wounds and help in rapid healing by turning the wound healing process into a proliferative phase $[96,97]$.

Both a sericin cream and a cream combining sericin with silver sulfadiazine promoted healing of full-thickness burn wounds in rats [95]. In addition, clinical studies have shown that a cream containing silk sericin in combination with silver sulfadiazine is safe and beneficial for treating burns [93]. Another study found that chitosan-sericin-silver nanocomposite films accelerated the process of burn wound healing through fibroblasts differentiation, angiogenesis, and collagen reorganization in animal models [90].

\subsection{Sericin for Oral Gargling}

Sericin inhibits tyrosinase activity and tyrosinase has close relation with skin pigmentation [84]. Accordingly, sericin has been used in cosmetics [59]. When a sericin gel is applied to the skin, the hydration level is increased [98]. Sericin treated skin shows a higher level of hydroxylproline than skin treated with distilled water [98]. Many elderly people suffer from xerostomia. Increased hydration by sericin used for oral gargling will be beneficial for those people. In addition, sericin accelerates wound healing [93]. Though the antimicrobial effect of sericin is controversial, increasing hydration and wound healing are enough to support the use of sericin as an oral gargling ingredient. Mulberry leaves are eaten by silkworm, and approximately $70 \%$ of mulberry proteins are used to produce silkworm cocoons [99]. Mulberry leaves have been used for oral gargle [100].

There have been few papers on sericin use for oral gargle. Only a single paper was found in Google scholar database. The effect on halitosis of a sericin gargle was compared with that of a commercial product [101]. The sericin gargle showed a lower level of hydrogen sulphide compared to the commercial product [101]. Currently, only one oral gargle containing silk protein is available in the market (Figure 7). Considering the beneficial effects of sericin on wound healing, the production of oral gargles containing sericin will probably increase in the near future.

\subsection{Sericin for Drug Delivery}

Drug delivery systems are used to improve the effectiveness of therapeutic agents through efficient targeting, modulated release, or stabilization of the molecular state of drugs [60]. An optimal effect of the drug is achieved with a reliable and controlled release profile, which is particularly important when the drug exerts undesirable side-effects. Silk proteins can be used as drug carriers, owing to their biocompatibility and adjustable morphology [102]. Sericin can be potentially applicable to drug delivery because of its chemical activity and $\mathrm{pH}$ responsiveness [60]. 


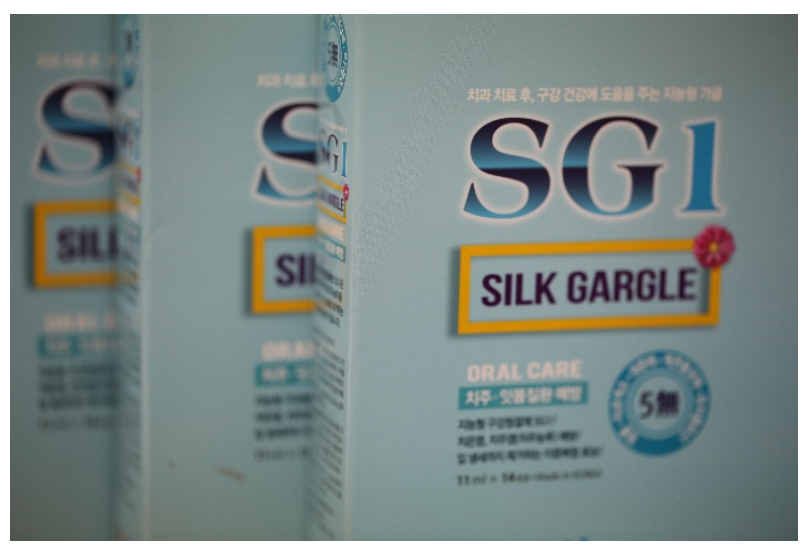

Figure 7. Commercially available oral gargle containing silk proteins.

Wang et al. reported a fabricated covalently crosslinked 3D pure sericin hydrogel that is injectable and exhibits several physical and chemical properties that promote a sustained drug release [103]. This hydrogel could serve as an efficient drug delivery system. Nishida et al. used sericin of different molecular sizes, concentrations, and forms, and evaluated the in vitro release and in vivo biodegradation of a charged protein, fluorescein isothiocyanate-albumin [104]. The higher the concentration of sericin, the longer was the release of the charged protein. In a rat model, this sericin preparation gradually decreased in size and weight, and the charged drug protein remained for 3 to 6 weeks or longer [104]. Therefore, sericin can be used as a drug delivery biomaterial. Zhang et al. reported that a sericin-alginate interpenetrating network hydrogel maintained controlled drug release at an adjustable rate [105]. This hydrogel adhered to cells and supported their proliferation, long-term survival, and migration and could be used as a versatile platform for drug delivery. Parisi et al. reported the use of sericin/poly(ethyl cyanoacrylate) nanospheres as a delivery system for fenofibrate, a lipophilic drug used as lipid-regulation agent [106]. This system increased the absorbable amount of fenofibrate by $70 \%$, improved plasma lipid levels, and decreased lipid storage in the liver, demonstrating its suitability for poorly water-soluble drugs.

\subsection{Sericin for Bone Regeneration}

Self-healing in severe bone defects is rare, necessitating treatment with artificial bone substitutes [107]. Sericin extracted from silk cocoons has been used in soft tissue engineering, for example, for epithelial and connective tissue repair [32]. The mechanical properties of sericin are suitable for soft tissue repair; however, the lack of mechanical strength makes sericin less applicable for bone regeneration $[60,107]$. Nevertheless, sericin can be used as an artificial bone substitute for severe bone defects if it is modified to improve its mechanical and bone-inducing properties [107].

Pure sericin is not used as a scaffold for bone tissue engineering because of its poor mechanical properties [60]. The nucleation of hydroxyapatite (HA) crystals is caused by anionic side chains that bind $\mathrm{Ca} 2+$, which means that the amount of acidic amino acids in sericin may affect the nucleation of hydroxyapatite crystals [108]. Zhang et al. reported that HA/sericin composite films could maintain the viability of human osteosarcoma MG-63 cells, owing to the deposition of HA and its three-dimensional structure; hence, these films could be applied for bone tissue engineering [109]. Veiga et al. reported the non-toxicity of HA/sericin nanocomposites, which increased cell viability [110]. Qi et al. fabricated a sericin methacyloyl/graphene oxide hydrogel with tunable mechanical strength and osteoinductive ability as a scaffold for the functional repair of bone tissue [107]. This scaffold had good biocompatibility, cell adhesion properties, cell proliferation and migration abilities, and osteogenic induction properties [107]. After implantation into a rat model of calvarial defect, this scaffold effectively promoted new bone regeneration and induced autologous bone marrow-derived 
mesenchymal stem cell differentiation, thereby achieving structural and functional repair within 12 weeks [107]. Therefore, sericin-based biomaterials can be used in bone tissue engineering.

\subsection{Sericin for Other Tissues}

In addition to the aforementioned tissue engineering applications, sericin has been used for cartilage or nerve regeneration. Dinescu et al. reported that a collagen-sericin scaffold improved with hyaluronic acid and chondroitin sulfate could be used as a temporary physical support for human adipose-derived stem cells for cartilage tissue engineering [111]. Hyaluronic acid and chondroitin sulfate are the most beneficial prochondrogenic factors used in the design of new biomaterials for cartilage tissue engineering, and adipose-derived stem cells have been demonstrated to exhibit high chondrogenic potential [111]. Qi et al. reported that artificial cartilages were effectively formed 8 weeks after injection of chondrocyte-laden sericin methacryloyl hydrogel in a rat model [112]. This artificial cartilage showed histological, molecular, and mechanical similarities to natural cartilage.

Xie et al. reported for the first time the use of a pure sericin conduit for peripheral nerve regeneration in a rat nerve injury model [113]. This sericin/silicone nerve guidance conduit can be used as an alternative to autologous nerve grafts to repair damaged peripheral nerves, as it induced functional recovery similar to that of an autologous nerve graft. Li et al. reported on nerve regeneration using a carbon nanotube/sericin nerve conduit in a rat nerve injury model [114]. This conduit can effectively promote the structural and functional recovery of nerves comparable to an autograft.

\section{Conclusions}

Sericin has different beneficial properties such as suitable chemical structure and biological activity, which vary depending on the extraction method employed. Many studies have been conducted on the biomedical applications of sericin, and recent studies on sericin for tissue engineering have received special attention. It is necessary to select an extraction method that can efficiently provide the necessary structure and impart the appropriate biological activity to sericin, according to the desired applications. This may encourage the commercialization of sericin for biomedical applications. In the future, more comparative studies on sericin biological activity depending on the extraction methods are needed.

Author Contributions: Conceptualization, methodology, Y.-Y.J.; validation, investigation, data curation, H.K.; writing-original draft preparation, J.-H.O.; writing—review and editing, Y.-Y.J.; supervision, J.-H.O.; funding acquisition, H.Y.K. All authors have read and agreed to the published version of the manuscript.

Funding: This study was conducted with the support of "Cooperative Research Program for Agriculture Science and Technology Development (Project no. PJ01313902)" Rural Development Administration, Republic of Korea. This study was carried out with the support of the 'Research Program for Agricultural Science \& Technology Development' (PJ012626022019), National Institute of Agricultural Science, Rural Development Administration, Republic of Korea.

Conflicts of Interest: The authors declare no conflict of interest.

\section{References}

1. Park, C.J.; Ryoo, J.; Ki, C.S.; Kim, J.W.; Kim, I.S.; Bae, D.G.; Um, I.C. Effect of molecular weight on the structure and mechanical properties of silk sericin gel, film, and sponge. Int. J. Biol. Macromol. 2018, 119, 821-832. [CrossRef] [PubMed]

2. Wang, R.; Zhu, Y.; Shi, Z.; Jiang, W.; Liu, X.; Ni, Q.-Q. Degumming of raw silk via steam treatment. J. Clean. Prod. 2018, 203, 492-497. [CrossRef]

3. Craig, C.L. Evolution of arthropod silks. Annu. Rev. Entomol. 1997, 42, 231-267. [CrossRef]

4. Ude, A.; Eshkoor, R.; Zulkifili, R.; Ariffin, A.; Dzuraidah, A.; Azhari, C. Bombyx mori silk fibre and its composite: A review of contemporary developments. Mater. Des. 2014, 57, 298-305. [CrossRef]

5. Kundu, S.C.; Dash, B.C.; Dash, R.; Kaplan, D.L. Natural protective glue protein, sericin bioengineered by silkworms: Potential for biomedical and biotechnological applications. Prog. Polym. Sci. 2008, 33, 998-1012. [CrossRef] 
6. Jo, Y.-Y.; Oh, J.-H. New resorbable membrane materials for guided bone regeneration. Appl. Sci. 2018, 8, 2157. [CrossRef]

7. Lu, S.; Wang, P.; Zhang, F.; Zhou, X.; Zuo, B.; You, X.; Gao, Y.; Liu, H.; Tang, H. A novel silk fibroin nanofibrous membrane for guided bone regeneration: A study in rat calvarial defects. Am. J. Transl. Res. 2015, 7, 2244-2253.

8. Song, J.M.; Shin, S.H.; Kim, Y.D.; Lee, J.Y.; Baek, Y.J.; Yoon, S.Y.; Kim, H.S. Comparative study of chitosan/fibroin-hydroxyapatite and collagen membranes for guided bone regeneration in rat calvarial defects: Micro-computed tomography analysis. Int. J. Oral Sci. 2014, 6, 87-93. [CrossRef]

9. Wang, F.; Wang, Y.; Tian, C.; Xu, S.; Wang, R.; Hou, K.; Chen, W.; Zhao, P.; Yu, L.; Lu, Z.; et al. Fabrication of the FGF1-functionalized sericin hydrogels with cell proliferation activity for biomedical application using genetically engineered Bombyx mori (B. mori) silk. Acta Biomater. 2018, 79, 239-252. [CrossRef]

10. Kim, H.J.; Kim, M.K.; Lee, K.H.; Nho, S.K.; Han, M.S.; Um, I.C. Effect of degumming methods on structural characteristics and properties of regenerated silk. Int. J. Biol. Macromol. 2017, 104, 294-302. [CrossRef]

11. Kwon, K.-J.; Seok, H. Silk Protein-Based Membrane for Guided Bone Regeneration. Appl. Sci. 2018, 8, 1214. [CrossRef]

12. Song, J.-Y.; Kim, S.-G.; Lee, J.-W.; Chae, W.-S.; Kweon, H.; Jo, Y.-Y.; Lee, K.-G.; Lee, Y.-C.; Choi, J.-Y.; Kim, J.-Y. Accelerated healing with the use of a silk fibroin membrane for the guided bone regeneration technique. Oral Surg. Oral Med. Oral Pathol. Oral Radiol. Endodontology 2011, 112, e26-e33. [CrossRef] [PubMed]

13. Altman, G.H.; Diaz, F.; Jakuba, C.; Calabro, T.; Horan, R.L.; Chen, J.; Lu, H.; Richmond, J.; Kaplan, D.L. Silk-based biomaterials. Biomaterials 2003, 24, 401-416. [CrossRef]

14. Tao, H.; Kaplan, D.L.; Omenetto, F.G. Silk materials-A road to sustainable high technology. Adv. Mater. 2012, 24, 2824-2837. [CrossRef] [PubMed]

15. Melke, J.; Midha, S.; Ghosh, S.; Ito, K.; Hofmann, S. Silk fibroin as biomaterial for bone tissue engineering. Acta Biomater. 2016, 31, 1-16. [CrossRef]

16. Min, B.M.; Lee, G.; Kim, S.H.; Nam, Y.S.; Lee, T.S.; Park, W.H. Electrospinning of silk fibroin nanofibers and its effect on the adhesion and spreading of normal human keratinocytes and fibroblasts in vitro. Biomaterials 2004, 25, 1289-1297. [CrossRef]

17. Jin, H.-J.; Chen, J.; Karageorgiou, V.; Altman, G.H.; Kaplan, D.L. Human bone marrow stromal cell responses on electrospun silk fibroin mats. Biomaterials 2004, 25, 1039-1047. [CrossRef]

18. Yu, K.; Lu, F.; Li, Q.; Chen, H.; Lu, B.; Liu, J.; Li, Z.; Dai, F.; Wu, D.; Lan, G. In situ assembly of Ag nanoparticles (AgNPs) on porous silkworm cocoon-based wound film: Enhanced antimicrobial and wound healing activity. Sci. Rep. 2017, 7, 2107. [CrossRef]

19. Yu, K.; Lu, F.; Li, Q.; Zou, Y.; Xiao, Y.; Lu, B.; Liu, J.; Dai, F.; Wu, D.; Lan, G. Accelerated wound-healing capabilities of a dressing fabricated from silkworm cocoon. Int. J. Biol. Macromol. 2017, 102, 901-913. [CrossRef]

20. Kim, M.K.; Kwak, H.W.; Kim, H.H.; Kwon, T.R.; Kim, S.Y.; Kim, B.J.; Park, Y.H.; Lee, K.H. Surface modification of silk fibroin nanofibrous mat with dextran for wound dressing. Fibers Polym. 2014, 15, 1137-1145. [CrossRef]

21. Lawrence, B.D.; Marchant, J.K.; Pindrus, M.A.; Omenetto, F.G.; Kaplan, D.L. Silk film biomaterials for cornea tissue engineering. Biomaterials 2009, 30, 1299-1308. [CrossRef] [PubMed]

22. Kim, J.; Kim, C.H.; Park, C.H.; Seo, J.N.; Kweon, H.; Kang, S.W.; Lee, K.G. Comparison of methods for the repair of acute tympanic membrane perforations: Silk patch vs. paper patch. Wound Repair Regen. Off. Publ. Wound Heal. Soc. Eur. Tissue Repair Soc. 2010, 18, 132-138. [CrossRef] [PubMed]

23. Zhang, X.; Wang, X.; Keshav, V.; Wang, X.; Johanas, J.T.; Leisk, G.G.; Kaplan, D.L. Dynamic culture conditions to generate silk-based tissue-engineered vascular grafts. Biomaterials 2009, 30, 3213-3223. [CrossRef] [PubMed]

24. Park, A.R.; Park, Y.-H.; Kim, H.J.; Kim, M.-K.; Kim, S.-G.; Kweon, H.; Kundu, S.C. Tri-layered silk fibroin and poly- $\varepsilon$-caprolactone small diameter vascular grafts tested in vitro and in vivo. Macromol. Res. 2015, 23, 924-936. [CrossRef]

25. Park, S.Y.; Ki, C.S.; Park, Y.H.; Lee, K.G.; Kang, S.W.; Kweon, H.Y.; Kim, H.J. Functional recovery guided by an electrospun silk fibroin conduit after sciatic nerve injury in rats. J. Tissue Eng. Regen. Med. 2015, 9, 66-76. [CrossRef]

26. Yucel, T.; Lovett, M.L.; Kaplan, D.L. Silk-based biomaterials for sustained drug delivery. J. Control. Release Off. J. Control. Release Soc. 2014, 190, 381-397. [CrossRef] 
27. Panilaitis, B.; Altman, G.H.; Chen, J.; Jin, H.J.; Karageorgiou, V.; Kaplan, D.L. Macrophage responses to silk. Biomaterials 2003, 24, 3079-3085. [CrossRef]

28. Rocha, L.K.; Favaro, L.I.; Rios, A.C.; Silva, E.C.; Silva, W.F.; Stigliani, T.P.; Guilger, M.; Lima, R.; Oliveira, J.M., Jr.; Aranha, N. Sericin from Bombyx mori cocoons. Part I: Extraction and physicochemical-biological characterization for biopharmaceutical applications. Process Biochem. 2017, 61, 163-177. [CrossRef]

29. Kumar, J.P.; Mandal, B.B. Antioxidant potential of mulberry and non-mulberry silk sericin and its implications in biomedicine. Free Radic. Biol. Med. 2017, 108, 803-818. [CrossRef]

30. Bari, E.; Perteghella, S.; Farago, S.; Torre, M.L. Association of silk sericin and platelet lysate: Premises for the formulation of wound healing active medications. Int. J. Biol. Macromol. 2018, 119, 37-47. [CrossRef]

31. Chlapanidas, T.; Farago, S.; Lucconi, G.; Perteghella, S.; Galuzzi, M.; Mantelli, M.; Avanzini, M.A.; Tosca, M.C.; Marazzi, M.; Vigo, D.; et al. Sericins exhibit ROS-scavenging, anti-tyrosinase, anti-elastase, and in vitro immunomodulatory activities. Int. J. Biol. Macromol. 2013, 58, 47-56. [CrossRef] [PubMed]

32. Kunz, R.I.; Brancalhao, R.M.; Ribeiro, L.F.; Natali, M.R. Silkworm Sericin: Properties and Biomedical Applications. BioMed Res. Int. 2016, 2016, 8175701. [CrossRef] [PubMed]

33. Aramwit, P.; Sangcakul, A. The effects of sericin cream on wound healing in rats. Biosci. Biotechnol. Biochem. 2007, 71, 2473-2477. [CrossRef] [PubMed]

34. Tsubouchi, K. Occlusive dressing consisting essentially of silk fibroin and silk sericin and its production. Japan Patent 11-070160A, 16 March 1999.

35. Kundu, B.; Kundu, S.C. Silk sericin/polyacrylamide in situ forming hydrogels for dermal reconstruction. Biomaterials 2012, 33, 7456-7467. [CrossRef] [PubMed]

36. Aramwit, P.; Siritienthong, T.; Srichana, T.; Ratanavaraporn, J. Accelerated healing of full-thickness wounds by genipin-crosslinked silk sericin/PVA scaffolds. Cells Tissues Organs 2013, 197, 224-238. [CrossRef]

37. Nagai, N.; Murao, T.; Ito, Y.; Okamoto, N.; Sasaki, M. Enhancing effects of sericin on corneal wound healing in Otsuka Long-Evans Tokushima fatty rats as a model of human type 2 diabetes. Biol. Pharm. Bull. 2009, 32, 1594-1599. [CrossRef]

38. Nagai, N.; Murao, T.; Ito, Y.; Okamoto, N.; Sasaki, M. Enhancing effects of sericin on corneal wound healing in rat debrided corneal epithelium. Biol. Pharm. Bull. 2009, 32, 933-936. [CrossRef]

39. Terada, S.; Nishimura, T.; Sasaki, M.; Yamada, H.; Miki, M. Sericin, a protein derived from silkworms, accelerates the proliferation of several mammalian cell lines including a hybridoma. Cytotechnology 2002, 40, 3-12. [CrossRef]

40. Terada, S.; Sasaki, M.; Yanagihara, K.; Yamada, H. Preparation of silk protein sericin as mitogenic factor for better mammalian cell culture. J. Biosci. Bioeng. 2005, 100, 667-671. [CrossRef]

41. Sasaki, M.; Kato, Y.; Yamada, H.; Terada, S. Development of a novel serum-free freezing medium for mammalian cells using the silk protein sericin. Biotechnol. Appl. Biochem. 2005, 42, 183-188. [CrossRef]

42. Morikawa, M.; Kimura, T.; Murakami, M.; Katayama, K.; Terada, S.; Yamaguchi, A. Rat islet culture in serum-free medium containing silk protein sericin. J. Hepato-Biliary-Pancreat. Surg. 2009, 16, 223-228. [CrossRef] [PubMed]

43. Ogawa, A.; Terada, S.; Kanayama, T.; Miki, M.; Morikawa, M.; Kimura, T.; Yamaguchi, A.; Sasaki, M.; Yamada, H. Improvement of islet culture with sericin. J. Biosci. Bioeng. 2004, 98, 217-219. [CrossRef]

44. Kato, N.; Sato, S.; Yamanaka, A.; Yamada, H.; Fuwa, N.; Nomura, M. Silk protein, sericin, inhibits lipid peroxidation and tyrosinase activity. Biosci. Biotechnol. Biochem. 1998, 62, 145-147. [CrossRef] [PubMed]

45. Fan, J.B.; Wu, L.P.; Chen, L.S.; Mao, X.Y.; Ren, F.Z. Antioxidant activities of silk sericin from silkworm Bombyx mori. J. Food Biochem. 2009, 33, 74-88. [CrossRef]

46. Takasu, Y.; Yamada, H.; Tsubouchi, K. Isolation of three main sericin components from the cocoon of the silkworm, Bombyx mori. Biosci. Biotechnol. Biochem. 2002, 66, 2715-2718. [CrossRef]

47. Dong, Z.; Guo, K.; Zhang, X.; Zhang, T.; Zhang, Y.; Ma, S.; Chang, H.; Tang, M.; An, L.; Xia, Q.; et al. Identification of Bombyx mori sericin 4 protein as a new biological adhesive. Int. J. Biol. Macromol. 2019, 132, 1121-1130. [CrossRef] [PubMed]

48. Okamoto, H.; Ishikawa, E.; Suzuki, Y. Structural analysis of sericin genes. Homologies with fibroin gene in the 5' flanking nucleotide sequences. J. Biol. Chem. 1982, 257, 15192-15199.

49. Michaille, J.J.; Couble, P.; Prudhomme, J.C.; Garel, A. A single gene produces multiple sericin messenger RNAs in the silk gland of Bombyx mori. Biochimie 1986, 68, 1165-1173. [CrossRef] 
50. Couble, P.; Michaille, J.J.; Garel, A.; Couble, M.L.; Prudhomme, J.C. Developmental switches of sericin mRNA splicing in individual cells of Bombyx mori silkgland. Dev. Biol. 1987, 124, 431-440. [CrossRef]

51. Michaille, J.J.; Garel, A.; Prudhomme, J.C. Cloning and characterization of the highly polymorphic Ser2 gene of Bombyx mori. Gene 1990, 86, 177-184. [CrossRef]

52. Garel, A.; Deleage, G.; Prudhomme, J.C. Structure and organization of the Bombyx mori sericin 1 gene and of the sericins 1 deduced from the sequence of the Ser 1B cDNA. Insect Biochem. Mol. Biol. 1997, 27, 469-477. [CrossRef]

53. Kludkiewicz, B.; Takasu, Y.; Fedic, R.; Tamura, T.; Sehnal, F.; Zurovec, M. Structure and expression of the silk adhesive protein Ser2 in Bombyx mori. Insect Biochem. Mol. Biol. 2009, 39, 938-946. [CrossRef] [PubMed]

54. Takasu, Y.; Yamada, H.; Tamura, T.; Sezutsu, H.; Mita, K.; Tsubouchi, K. Identification and characterization of a novel sericin gene expressed in the anterior middle silk gland of the silkworm Bombyx mori. Insect Biochem. Mol. Biol. 2007, 37, 1234-1240. [CrossRef] [PubMed]

55. Takasu, Y.; Hata, T.; Uchino, K.; Zhang, Q. Identification of Ser2 proteins as major sericin components in the non-cocoon silk of Bombyx mori. Insect Biochem. Mol. Biol. 2010, 40, 339-344. [CrossRef] [PubMed]

56. Dong, Z.; Zhao, P.; Zhang, Y.; Song, Q.; Zhang, X.; Guo, P.; Wang, D.; Xia, Q. Analysis of proteome dynamics inside the silk gland lumen of Bombyx mori. Sci. Rep. 2016, 6, 21158. [CrossRef] [PubMed]

57. Dong, Z.; Zhao, P.; Wang, C.; Zhang, Y.; Chen, J.; Wang, X.; Lin, Y.; Xia, Q. Comparative proteomics reveal diverse functions and dynamic changes of Bombyx mori silk proteins spun from different development stages. J. Proteome Res. 2013, 12, 5213-5222. [CrossRef]

58. Rajput, S.; Singh, M.K. Sericin-a unique biomaterial. IOSR J. Polym. Text. Eng. 2015, 2, $29-35$.

59. Padamwar, M.; Pawar, A. Silk sericin and its applications: A review. J. Sci. Ind. Res. 2004, 63, 323-329.

60. Lamboni, L.; Gauthier, M.; Yang, G.; Wang, Q. Silk sericin: A versatile material for tissue engineering and drug delivery. Biotechnol. Adv. 2015, 33, 1855-1867. [CrossRef]

61. Kumar, J.P.; Bhardwaj, N.; Mandal, B.B. Cross-linked silk sericin-gelatin 2D and 3D matrices for prospective tissue engineering applications. RSC Adv. 2016, 6, 105125-105136. [CrossRef]

62. Da Silva, T.; Junior, A.D.S.; Ribani, M.; Vieira, M.; Gimenes, M.; Da Silva, M.G. Evaluation of molecular weight distribution of sericin in solutions concentrated via precipitation by ethanol and precipitation by freezing/thawing. Chem. Eng. Trans. 2014, 38, 103-108.

63. Aramwit, P.; Damrongsakkul, S.; Kanokpanont, S.; Srichana, T. Properties and antityrosinase activity of sericin from various extraction methods. Biotechnol. Appl. Biochem. 2010, 55, 91-98. [CrossRef] [PubMed]

64. Aramwit, P.; Kanokpanont, S.; Nakpheng, T.; Srichana, T. The effect of sericin from various extraction methods on cell viability and collagen production. Int. J. Mol. Sci. 2010, 11, 2200-2211. [CrossRef] [PubMed]

65. Wray, L.S.; Hu, X.; Gallego, J.; Georgakoudi, I.; Omenetto, F.G.; Schmidt, D.; Kaplan, D.L. Effect of processing on silk-based biomaterials: Reproducibility and biocompatibility. J. Biomed. Mater. Res. Part B Appl. Biomater. 2011, 99, 89-101. [CrossRef]

66. Kaur, J.; Rajkhowa, R.; Afrin, T.; Tsuzuki, T.; Wang, X. Facts and myths of antibacterial properties of silk. Biopolymers 2014, 101, 237-245. [CrossRef]

67. Mason, R. Fabrics for atopic dermatitis. J. Fam. Health Care 2008, 18, 63-65.

68. Aramwit, P.; Kanokpanont, S.; De-Eknamkul, W.; Srichana, T. Monitoring of inflammatory mediators induced by silk sericin. J. Biosci. Bioeng. 2009, 107, 556-561. [CrossRef]

69. Jo, Y.-Y.; Kweon, H.; Kim, D.-W.; Baek, K.; Kim, M.-K.; Kim, S.-G.; Chae, W.-S.; Choi, J.-Y.; Rotaru, H. Bone regeneration is associated with the concentration of tumour necrosis factor- $\alpha$ induced by sericin released from a silk mat. Sci. Rep. 2017, 7, 1-12. [CrossRef]

70. Eidet, J.R.; Reppe, S.; Pasovic, L.; Olstad, O.K.; Lyberg, T.; Khan, A.Z.; Fostad, I.G.; Chen, D.F.; Utheim, T.P. The Silk-protein Sericin Induces Rapid Melanization of Cultured Primary Human Retinal Pigment Epithelial Cells by Activating the NF-kappaB Pathway. Sci. Rep. 2016, 6, 22671. [CrossRef]

71. Jo, Y.Y.; Kim, D.W.; Choi, J.Y.; Kim, S.G. 4-Hexylresorcinol and silk sericin increase the expression of vascular endothelial growth factor via different pathways. Sci. Rep. 2019, 9, 3448. [CrossRef]

72. Kim, D.W.; Jo, Y.Y.; Garagiola, U.; Choi, J.Y.; Kang, Y.J.; Oh, J.H.; Kim, S.G. Increased Level of Vascular Endothelial Growth Factors by 4-hexylresorcinol is Mediated by Transforming Growth Factor-beta1 and Accelerates Capillary Regeneration in the Burns in Diabetic Animals. Int. J. Mol. Sci. 2020, 21, 3473. [CrossRef]

73. Kim, J.W.; Jo, Y.Y.; Kim, J.Y.; Oh, J.H.; Yang, B.E.; Kim, S.G. Retrospective comparative clinical study for silk mat application into extraction socket. Maxillofac. Plast. Reconstr. Surg. 2019, 41, 16. [CrossRef] 
74. Kim, J.W.; Jo, Y.Y.; Kweon, H.Y.; Kim, D.W.; Kim, S.G. The effects of proteins released from silk mat layers on macrophages. Maxillofac. Plast. Reconstr. Surg. 2018, 40, 10. [CrossRef]

75. Kim, D.W.; Jo, Y.Y.; Kweon, H.Y.; Kim, S.G. Different level of tumor necrosis factor- $\alpha$ expression after administration of silk sericin fraction in RAW264.7 cells. Int. J. Ind. Entomol. 2020, 41, 1-5.

76. Aramwit, P.; Towiwat, P.; Srichana, T. Anti-inflammatory potential of silk sericin. Nat. Prod. Commun. 2013, 8, 501-504. [CrossRef]

77. Chlapanidas, T.; Perteghella, S.; Leoni, F.; Farago, S.; Marazzi, M.; Rossi, D.; Martino, E.; Gaggeri, R.; Collina, S. TNF-alpha blocker effect of naringenin-loaded sericin microparticles that are potentially useful in the treatment of psoriasis. Int. J. Mol. Sci. 2014, 15, 13624-13636. [CrossRef]

78. Song, C.J.; Fu, X.M.; Li, J.; Chen, Z.H. Effects of sericine on TGF-beta1/Smad3 signal pathway of diabetic mephropathy rats kidney. Zazhi Chin. J. Appl. Physiol. 2011, 27, 102-105.

79. Dash, R.; Acharya, C.; Bindu, P.C.; Kundu, S.C. Antioxidant potential of silk protein sericin against hydrogen peroxide-induced oxidative stress in skin fibroblasts. BMB Rep. 2008, 41, 236-241. [CrossRef]

80. Tsubouchi, K.; Igarashi, Y.; Takasu, Y.; Yamada, H. Sericin enhances attachment of cultured human skin fibroblasts. Biosci. Biotechnol. Biochem. 2005, 69, 403-405. [CrossRef]

81. Martinez-Mora, C.; Mrowiec, A.; Garcia-Vizcaino, E.M.; Alcaraz, A.; Cenis, J.L.; Nicolas, F.J. Fibroin and sericin from Bombyx mori silk stimulate cell migration through upregulation and phosphorylation of c-Jun. PLoS ONE 2012, 7, e42271. [CrossRef]

82. Nayak, S.; Dey, T.; Naskar, D.; Kundu, S.C. The promotion of osseointegration of titanium surfaces by coating with silk protein sericin. Biomaterials 2013, 34, 2855-2864. [CrossRef] [PubMed]

83. Schurink, M.; van Berkel, W.J.; Wichers, H.J.; Boeriu, C.G. Novel peptides with tyrosinase inhibitory activity. Peptides 2007, 28, 485-495. [CrossRef]

84. Kurioka, A.; Kurioka, F.; Yamazaki, M. Characterization of sericin powder prepared from citric acid-degraded sericin polypeptides of the silkworm, Bombyx Mori. Biosci. Biotechnol. Biochem. 2004, 68, 774-780. [CrossRef]

85. Kumari, S.; Elancheran, R.; Devi, R. Phytochemical screening, antioxidant, antityrosinase, and antigenotoxic potential of Amaranthus viridis extract. Indian J. Pharmacol. 2018, 50, 130-138. [CrossRef] [PubMed]

86. Zuo, A.R.; Dong, H.H.; Yu, Y.Y.; Shu, Q.L.; Zheng, L.X.; Yu, X.Y.; Cao, S.W. The antityrosinase and antioxidant activities of flavonoids dominated by the number and location of phenolic hydroxyl groups. Chin. Med. 2018, 13, 51. [CrossRef] [PubMed]

87. Maxson, S.; Lopez, E.A.; Yoo, D.; Danilkovitch-Miagkova, A.; Leroux, M.A. Concise review: Role of mesenchymal stem cells in wound repair. Stem Cells Transl. Med. 2012, 1, 142-149. [CrossRef]

88. Guo, S.; Dipietro, L.A. Factors affecting wound healing. J. Dent. Res. 2010, 89, 219-229. [CrossRef]

89. Garg, V.K.; Paliwal, S.K. Wound-healing activity of ethanolic and aqueous extracts of Ficus benghalensis. J. Adv. Pharm. Technol. Res. 2011, 2, 110-114. [CrossRef]

90. Shah, A.; Ali Buabeid, M.; Arafa, E.A.; Hussain, I.; Li, L.; Murtaza, G. The wound healing and antibacterial potential of triple-component nanocomposite (chitosan-silver-sericin) films loaded with moxifloxacin. Int. J. Pharm. 2019, 564, 22-38. [CrossRef]

91. Salas Campos, L.; Fernandes Mansilla, M.; Martinez de la Chica, A.M. Topical chemotherapy for the treatment of burns. Rev. Enferm. 2005, 28, 67-70.

92. Khorasani, G.; Hosseinimehr, S.J.; Azadbakht, M.; Zamani, A.; Mahdavi, M.R. Aloe versus silver sulfadiazine creams for second-degree burns: A randomized controlled study. Surg. Today 2009, 39, 587-591. [CrossRef] [PubMed]

93. Aramwit, P.; Palapinyo, S.; Srichana, T.; Chottanapund, S.; Muangman, P. Silk sericin ameliorates wound healing and its clinical efficacy in burn wounds. Arch. Dermatol. Res. 2013, 305, 585-594. [CrossRef] [PubMed]

94. Aramwit, P.; Kanokpanont, S.; De-Eknamkul, W.; Kamei, K.; Srichana, T. The effect of sericin with variable amino-acid content from different silk strains on the production of collagen and nitric oxide. J. Biomater. Sci. Polym. Ed. 2009, 20, 1295-1306. [CrossRef] [PubMed]

95. Aramwit, P.; Kanokpanont, S.; Punyarit, P.; Srichana, T. Effectiveness of inflammatory cytokines induced by sericin compared to sericin in combination with silver sulfadiazine cream on wound healing. Wounds A Compend. Clin. Res. Pract. 2009, 21, 198-206.

96. Gilotra, S.; Chouhan, D.; Bhardwaj, N.; Nandi, S.K.; Mandal, B.B. Potential of silk sericin based nanofibrous mats for wound dressing applications. Mater. Sci. Eng. CMater. Biol. Appl. 2018, 90, 420-432. [CrossRef] 
97. Chouhan, D.; Mandal, B.B. Silk biomaterials in wound healing and skin regeneration therapeutics: From bench to bedside. Acta Biomater. 2020, 103, 24-51. [CrossRef]

98. Padamwar, M.N.; Pawar, A.P.; Daithankar, A.V.; Mahadik, K. Silk sericin as a moisturizer: An in vivo study. J. Cosmet. Dermatol. 2005, 4, 250-257. [CrossRef]

99. Oka, S. Mulberry (Morus alba L.). Biotechnol. Agric. For. 1986, 1, 384-392.

100. Kumar, H.A.; Muralidhar, T.; Acharya, S.; Das, M.J. EMS induced morphometric biomass and phytochemical variations in Morus species (Genotype RFS135). J. Exp. Agric. Int. 2013, 3, 43-55. [CrossRef]

101. Kang, Y.-J.; Ahn, S.-H.; Kim, Y.-W.; Jo, Y.-Y.; Kweon, H.; Kim, S.-G. Non-randomized, one way cross-over, open label preliminary clinical trial for silk protein based oral gargling. Int. J. Ind. Entomol. 2019, 38, $14-17$.

102. Hardy, J.G.; Römer, L.M.; Scheibel, T.R. Polymeric materials based on silk proteins. Polymer 2008, 49, 4309-4327. [CrossRef]

103. Wang, Z.; Zhang, Y.; Zhang, J.; Huang, L.; Liu, J.; Li, Y.; Zhang, G.; Kundu, S.C.; Wang, L. Exploring natural silk protein sericin for regenerative medicine: An injectable, photoluminescent, cell-adhesive 3D hydrogel. Sci. Rep. 2014, 4, 7064. [CrossRef] [PubMed]

104. Nishida, A.; Yamada, M.; Kanazawa, T.; Takashima, Y.; Ouchi, K.; Okada, H. Sustained-release of protein from biodegradable sericin film, gel and sponge. Int. J. Pharm. 2011, 407, 44-52. [CrossRef] [PubMed]

105. Zhang, Y.; Liu, J.; Huang, L.; Wang, Z.; Wang, L. Design and performance of a sericin-alginate interpenetrating network hydrogel for cell and drug delivery. Sci. Rep. 2015, 5, 12374. [CrossRef] [PubMed]

106. Parisi, O.I.; Fiorillo, M.; Scrivano, L.; Sinicropi, M.S.; Dolce, V.; Iacopetta, D.; Puoci, F.; Cappello, A.R. Sericin/Poly(ethylcyanoacrylate) Nanospheres by Interfacial Polymerization for Enhanced Bioefficacy of Fenofibrate: In Vitro and In Vivo Studies. Biomacromolecules 2015, 16, 3126-3133. [CrossRef] [PubMed]

107. Qi, C.; Deng, Y.; Xu, L.; Yang, C.; Zhu, Y.; Wang, G.; Wang, Z.; Wang, L. A sericin/ graphene oxide composite scaffold as a biomimetic extracellular matrix for structural and functional repair of calvarial bone. Theranostics 2020, 10, 741-756. [CrossRef]

108. Yang, M.; Shuai, Y.; Zhang, C.; Chen, Y.; Zhu, L.; Mao, C.; OuYang, H. Biomimetic nucleation of hydroxyapatite crystals mediated by Antheraea pernyi silk sericin promotes osteogenic differentiation of human bone marrow derived mesenchymal stem cells. Biomacromolecules 2014, 15, 1185-1193. [CrossRef]

109. Zhang, H.; Wang, X.; Min, S.; Mandal, M.; Yang, M.; Zhu, L. Hydroxyapatite/sericin composite film prepared through mineralization of flexible ethanol-treated sericin film with simulated body fluids. Ceram. Int. 2014, 40, 985-991. [CrossRef]

110. Veiga, A.; Castro, F.; Reis, C.C.; Sousa, A.; Oliveira, A.L.; Rocha, F. Hydroxyapatite/sericin composites: A simple synthesis route under near-physiological conditions of temperature and $\mathrm{pH}$ and preliminary study of the effect of sericin on the biomineralization process. Mater. Sci. Eng. C 2020, 108, 110400. [CrossRef]

111. Dinescu, S.; Galateanu, B.; Albu, M.; Lungu, A.; Radu, E.; Hermenean, A.; Costache, M. Biocompatibility assessment of novel collagen-sericin scaffolds improved with hyaluronic Acid and chondroitin sulfate for cartilage regeneration. BioMed Res. Int. 2013, 2013, 598056. [CrossRef]

112. Qi, C.; Liu, J.; Jin, Y.; Xu, L.; Wang, G.; Wang, Z.; Wang, L. Photo-crosslinkable, injectable sericin hydrogel as 3D biomimetic extracellular matrix for minimally invasive repairing cartilage. Biomaterials 2018, 163, 89-104. [CrossRef]

113. Xie, H.; Yang, W.; Chen, J.; Zhang, J.; Lu, X.; Zhao, X.; Huang, K.; Li, H.; Chang, P.; Wang, Z.; et al. A silk sericin/silicone nerve guidance conduit promotes regeneration of a transected sciatic nerve. Adv. Healthc. Mater. 2015, 4, 2195-2205. [CrossRef]

114. Li, X.; Yang, W.; Xie, H.; Wang, J.; Zhang, L.; Wang, Z.; Wang, L. CNT/Sericin Conductive Nerve Guidance Conduit Promotes Functional Recovery of Transected Peripheral Nerve Injury in a Rat Model. ACS Appl. Mater. Interfaces 2020, 12, 36860-36872. [CrossRef]

Publisher's Note: MDPI stays neutral with regard to jurisdictional claims in published maps and institutional affiliations. 